\title{
Physical Examination Subcategory
}

National Cancer Institute

\section{Source}

National Cancer Institute. Physical Examination Subcategory. NCI Thesaurus. Code C83355.

A subdivision of physical examination data. 